\title{
Assessing the Interdependence of SSC EFL Testing, Teaching and Materials; an Evaluation of SSC Curriculum
}

\author{
Mohammed Humayun Kabir ${ }^{1}$, Noor Saazai Bt Mat Saad ${ }^{2}$ \\ ${ }^{1}$ Department of English Language and Literature, IIUC, Chittagong, Bangladesh \\ ${ }^{2}$ Faculty of Major Language Studies, USIM, Nilai, Malaysia \\ Email: humayun002003@yahoo.com
}

How to cite this paper: Kabir, M. H., \& Saad, N. S. B. M. (2020). Assessing the Interdependence of SSC EFL Testing, Teaching and Materials; an Evaluation of SSC Curriculum. Creative Education, 11, 16-37. https://doi.org/10.4236/ce.2020.111002

Received: November 27, 2019

Accepted: January 10, 2020

Published: January 13, 2020

Copyright $\odot 2020$ by author(s) and Scientific Research Publishing Inc. This work is licensed under the Creative Commons Attribution International License (CC BY 4.0).

http://creativecommons.org/licenses/by/4.0/

\section{Open Access}

\begin{abstract}
Secondary School Certificate (SSC) is an "O" level equivalent grade in Bangladesh. Numerous studies found that SSC EFL tests have harmful backwash effects as teachers and learners have become "test-wise", because same test pattern continues since 1996. It is a sign of deviation from the SSC curriculum which is designed following CLT principles. It is further criticised that SSC students and their teachers exceedingly depend on commercially published Note/Guidebooks although there are two officially published textbooks known as English For Today (English $1^{\text {st }}$ Paper) and English Grammar and Composition (English $2^{\text {nd }}$ Paper) edited and published by National Curriculum Textbook Board (NCTB). Thus, this study was designed to appraise the interdependence of SSC EFL testing, teaching and teaching-learning materials in the light of the guidelines of the SSC English curriculum. To collect data, in this study, we used two methods: namely document analysis and survey. The former includes SSC curriculum and English test papers, while the latter involves a questionnaire. The analysis of the data revealed that SSC EFL tests affect teaching of English at SSC level and also influence teachers and students when they select reading/teaching materials. It is also found that the curriculum guidelines are not followed in the classroom teaching and test design. Exam centric teaching is prevalent everywhere. We noticed a mismatch among the mandated curriculum, classroom teaching and the teaching materials used which might foil the endeavour to achieve the objectives of the secondary English curriculum. Conventional test pattern immensely influences the teachers' teaching and their selection of teaching materials. This study recommends some specific measures including the reformation of SSC EFL testing.
\end{abstract}

\section{Keywords}

SSC, Materials, Curriculum, CLT, Testing, Backwash, Evaluation, CLT, EFL 


\section{Introduction}

Secondary School Certificate (SSC) is an "O" level equivalent grade in Bangladesh. Students of Grade/Level-X are known as SSC level students. After completing two years of study in Grade/Level-IX and X, students appear at SSC examination. The National Curriculum 2012 states that Communicative Language Teaching (CLT) is the functional teaching approach at Secondary School Certificate (SSC) level since 1995 (National Curriculum, 2012: p. 1). Hence, English language teaching and testing methodology are supposed to uphold CLT principles at the SSC level. The curriculum claims that English language teaching materials have been developed in line with CLT principles and it also suggests teachers to carry out teaching following the CLT guidelines. The goal of teaching English is "to help learners acquire the basic skills of English language for effective communications at different spheres including contemporary work places, and higher education" (National Curriculum, 2012: p. 11). Despite the fact that the official curricular documents claim that CLT was introduced in 1995 at secondary level in Bangladesh, CLT principles are not followed entirely in the schools and colleges till date (Sultana, 2018). The implementation of CLT in secondary and higher secondary levels is doubted (Billah, 2015; Ali \& Walker, 2014; Hamid \& Baldauf, 2008; English in Action, 2014; Haider \& Chowdhury, 2012; Kabir, 2015).

The success of CLT in terms of developing communicative competence is questioned very often in Bangladesh. The influence of Grammar Translation Method (GTM) is still noticed in the classroom teaching and learning activities. It is also observed that the teaching materials that are randomly used are not authentic materials. This is obviously contradictory with the principles of CLT. As CLT replaced GTM based curriculum, it was expected that there would be conspicuous changes in test design. However, studies have identified that tests have not been devised to measure communicative competence, because they (tests) still maintain a legacy with the conventional testing method of GTM. Numerous of studies identified that the faulty testing system of SSC thwarts the attempt of the implementation of CLT. They argue that SSC EFL tests lack validity and reliability (see Kabir, 2007; Kabir, 2008; Kabir, 2009). As the test pattern has remained unchanged years together, test items have become predictable. For this reason, teachers tend to teach some commonly tested (which are regularly tested) items only, and learners also concentrate on those items.

Generally, the motto of any test taker is to obtain an impressive grade in the test, particularly, when it is a high-stakes achievement test. SSC test functions like a gatekeeper which determines the future career of a student. SSC results decide whether a student's admission will be permitted or rejected in a particular college. That is why students and guardians frantically try to ensure good grades at SSC. As a consequence, the SSC test has a substantial influence on teaching and learning. It is widely noticed that all effort is dedicated to ensuring good grades. As good results are the desire of all main stakeholders, it is observed that 
the total educational arrangement is test centric in the context of Bangladesh (Billah, 2015; Ali, Hamid, \& Hardy, 2018; Rahman \& Pandia 2018; Al Amin \& Greenwood, 2018). As a consequence, it is noticed that curricular goals are undermined.

Students and guardians look for alternative teaching arrangement as they consider the formal school teaching is not enough to ensure a good grade at SSC. As a consequence, the commercialisation of education is soaring throughout the country. Students frequently go to private tutors, commercial coaching centres and they tend to use commercially published Note/Guide books instead of NCTB textbooks to prepare themselves for the test. As a result, the market of shadow education is soaring alarmingly (UNESCO, 2018). A crazy race is prevailing in the society to secure good grades where teachers, students, school authorities, guardians and other stakeholders join their hands (UNESCO, 2018; EIA, 2014). Ensuring a good result has become the ultimate goal of the parents and students. This attitude has shifted the focus of English language teaching and learning in Bangladesh. It appears that achieving a good grade is more essential than developing language proficiency. It appears that the guidelines of the SSC curriculum regarding EFL teaching and learning are ignored. It is important to explore whether teaching, testing and English teaching materials are synchronised with the curricular goals and objectives. Besides, it has to be studied whether SSC tests have any sort of influence on teachers' teaching activities and their selection of materials.

\subsection{The Rationale of the Study}

Any superficial analysis might show that present SSC EFL tests ignore two vital language skills, namely Listening and Speaking which are crucial for developing communication skill among the language users in any context. Past test papers show that no marks are allocated for Listening and Speaking skills. For this reason, teachers do not teach those skills and learners also do not show any interest in practising those skills. In spite of that, it is officially claimed that CLT is functional at the secondary level in Bangladesh. Unquestionably, there exists a very intricate and close relationship between testing, teaching and teaching materials in a teaching paradigm where CLT is functional. All of these three vital components mutually contribute to each other to make CLT effective. Unless they are aligned well, SSC English curriculum may fail to achieve the desired goals and objectives. So, a study is necessary to examine the interdependence of SSC EFL testing, teaching and teaching materials.

\subsection{Significance of the Study}

In the context of Bangladesh, generally (school) teachers do not prepare teaching materials although the prescribed curriculum directs that teachers should design and use authentic materials as the curriculum suggests that communicative language teaching should be practised. In a CLT based teaching context, a kind of interdependence prevails between SSC EFL tests, classroom teaching and teach- 
ing materials. In this study, we endeavour to examine the nature of this stated interdependence. So far our knowledge goes the nature of interdependence between SSC EFL tests, teaching and teaching materials is not studied thoroughly. That is why, it is expected that this study will benefit all who are involved with the education administration of Bangladesh.

\subsection{Research Questions}

The following research questions have been framed to investigate the level of interdependence of SSC EFL testing, teaching and teaching materials:

1) How do SSC EFL tests influence classroom teaching of English and selection of teaching materials?

2) How are the SSC EFL tests, teaching and teaching materials reciprocally related to one another?

\section{Literature Review}

It is a curriculum which states the purposes of an educational program, and according to the purposes, a detailed plan is laid out to implement the program where the users of the curriculum are informed about the teaching contents and methodology of teaching. In addition to that, it states the assessment policy. Nunan (1988: p. 158) maintains that a curriculum is the "principles and procedures for the planning, implementation and evaluation and management of an educational program." Whereas, Richards (2001) holds that a curriculum "describes an interrelated set of processes that focuses on designing, revising, implementing, and evaluating language programs" (p. 2). Indeed, curricula make a general statement about language learning, rationale of learning a language, assessment policy, and the role relationships of teachers and learners.

Richards, Platt and Weber (1985: p. 70) hold that curriculum refers to "an educational program which states:

1) the educational purpose of the program

2) the content, teaching procedures and learning experiences which will be necessary to achieve this purpose

3) some means for assessing whether or not the educational ends have been achieved".

\subsection{SSC English Curriculum}

Grammar Translation Method (GTM) had been functional until 1995 in Bangladesh. However, the policymakers of the country found that the GTM - based curriculum was "excessively theoretical and informative, and leads learners to rote learning” (National Curriculum, 2012: p. 1). GTM-based curriculum insisted on learning a language for using it by following a deductive approach, but the present curriculum prioritises using language to learn it by following an inductive approach. One of the core objectives of the present curriculum is to "help learners acquire the basic skills of English language for effective commu- 
nications at different spheres including contemporary workplaces, and higher education" (National Curriculum, 2012: p. 11). Hence, a CLT based curriculum was introduced to develop communication skills by emphasising equal importance on four language skills. It views language learning pursuit is a process rather than a product. The functional curriculum posits that "learning can take place easily and in less time if learners actively participate in the learning process" (National Curriculum, 2012: p. 17). It is clearly understood that a learner-centered classroom is preferred here. This study considered the NC intending to examine the key aspects of the SSC curriculum in relation with tests, teaching and teaching materials.

\subsection{Teaching Materials for SSC Students}

National Curriculum and Textbook Board (NCTB) is in charge of developing textbooks to carryout teaching and learning activities smoothly in line with the present CLT based curriculum. English For Today (English 1 ${ }^{\text {st }}$ Paper) and English Grammar and Composition (English $2^{\text {nd }}$ Paper) are developed by NCTB for SSC students. Shaha (2010) reiterates that "the English For Today textbooks have been developed to help students attain competency in all four language skills, i.e., listening, speaking, reading and writing. The contents and illustration of the textbook have been developed to suit the learners' age and cognitive level" (p. 3). So, it is understood that the NCTB experts designed the textbooks as the effective tools of teaching and learning language to achieve SSC curricular goals. The existing curriculum encourages practicing teachers to use "supplementary reading materials to develop learners' reading skills (National Curriculum, 2012: p. 73). The Teacher's Curriculum Guide (TCG) mentions that the objectives of learning English at SSC are "to acquire competence in all four language skills ... to develop creativity and critical thinking through English language..." (Teacher's Curriculum Guide, TCG, p. 23).

It is expected and suggested that authentic materials (where necessary) have to be used for teaching purpose. However, most of the time, teachers and students prefer to use guide/notebooks. SSC is a public exam which is centrally arranged by the Ministry of Education after the completion of a two years' of intensive teaching. Teachers have to complete the SSC English syllabus and prepare the students for the final (SSC) test. The nature of the test suggests that SSC is a kind of achievement test as it is "directly related to language courses" and its purpose is to "establish how successful individual students, groups of students, or the courses themselves have been in achieving objectives" (Hughes, 2003: p. 10) of the curriculum.

\subsection{Achievement Test}

"When we administer an educational achievement test, we want to be confident that the resulting scores validly indicate what the test takers know and can do. To accomplish this goal, we develop a carefully designed test that addresses the intended construct or content domain and then administers the test under standardized conditions" Wise, Kuhfeld and Soland (2019: p. 183). Achievement 
tests are designed by following a prescribed syllabus. After completing the contents of the prescribed textbook(s) in a stipulated time session, this test is arranged in order to evaluate how much the learners have achieved in that particular academic session.

Experts classified achievement test into two types: 1) Final achievement test and 2) Progress achievement test. It is understood that the SSC EFL test is a final achievement test because they are "administered at the end of a course of a study" (Hughes, 2003: p. 10).

\subsection{Communicative Language Test}

Communicative language tests are developed to assess communicative competence. Cramming and rote memorization is unprecedented where communicative tests are practiced. Phan (2008) holds that "communicative language tests are used to measure language learners' ability to take part in acts of communication or to use language in real-life situations" (p. 3). Presumably, a Communicative language test includes all four major language skills, i.e. reading, writing, speaking and listening skills. Thus there is no scope to single out any language skill or skills in a teaching-learning context.

Phan (2008) scrutinizes Brown (2005) and determines that "there are five requirements for setting up a communicative test. These include meaningful communication, authentic situation, unpredictable language input, creative language output, and integrated language skills" (p. 21). Weir (1990) discussed the basic features of a CLT-based test in a very persuasive way. Ali and Sultana (2016) identified the following fundamental features of a CLT based test:

- unpredictable

- subject to time pressure

- interaction-based

- has a linguistic and sociocultural context

- purposeful

- uses authentic materials

- outcome evaluated" (p. 120).

Teaching is not at all an isolated activity; rather, it is deeply linked with test preparation activity where communicative tests are used. If a test is an achievement test, it has to be very closely aligned with classroom teaching so that learners can prepare themselves for the tests. Hence, the relationship between teaching and testing is very intricate at the SSC level. Phan (2008) suggests that "it is reasonable and necessary to implement communicative tests in harmony with the communicative teaching method to assess learners' ability to communicate" (p. 9).

According to the National Curriculum (NC) 2012, SSC EFL tests are supposed to be CLT based. However, it is manifested that two vital communication skills, i.e., speaking and listening skills are not assessed in SSC which suggests that all basic four language skills are not tested. This study was designed to ascertain the 
interdependence between SSC EFL tests, teaching, and teaching and learning materials.

\subsection{Relationship between Testing and Teaching}

Teachers need to consider test patterns and devise lectures in accordance with the course objectives so that the objectives of that course are achieved. There exists a very close relationship between the language program and the testing system in a teaching context where achievement test is arranged. Carroll (1980: p. 5) finds "the interactive relationship between the language program and the testing system." Hence, Teachers need to design their lesson plans giving priority to the test where a high-stakes achievement test is practised. A context where communicative language testing is in practice, tests have remarkable impact on teaching. Weir (1990: p. 27) opines that "a communicative approach to language teaching is more likely to be adopted when the test at the end of a course of instruction is itself communicative".

Officially CLT is accepted as a language teaching approach in our context. The ever-rising demand for English proficiency in the job market and young people's growing tendency to migrate in the advanced world, especially to the BANA (Britain, Australia \& North America) countries have had a huge impact on English teaching and learning. The overwhelming majority depend on teachers for formal and informal learning to improve their English language skills (UNESCO, 2018).

On top of that English language teaching and learning at school and college levels are entirely controlled by teachers. It is expected that teachers will prepare students during these two years for the final achievement test, i.e., SSC. Hence, it is an undeniable fact that there exists an intricate relationship between teaching and testing in the context of Bangladesh.

The effects of tests on teaching and learning can be considered as "backwash" or "washback." The succeeding section includes a discussion on washback to explore the term and to recognize its existence in the education system, especially at SSC level.

\subsection{Washback}

Academic tests cannot be neutral. Highs-takes tests are more powerful as they function as the gatekeepers. It is generally perceived that tests might have a positive/negative influence on teaching and learning. This influence or effect of any test is known as washback or backwash. When teachers need to teach more areas, and learners need to study more seriously than they usually do due to test influence, it is beneficial washback. On the contrary, due to the predictable character of a test, if teachers do not need to teach elaborately and learners can ignore an important part from the syllabus, it can be treated as harmful backwash. "Washback or backwash refers to the effects of assessment practices on students, teachers and administrators, and indirectly on schools and communities" (Tok- 
soz \& Kilickaya, 2017: p. 185). Sultana (2018) holds that "washback is the influence of high-stakes test on classroom instruction, both on teaching and learning" (p. 469). Besides, Thaidan (2015) identifies that washback "has already bi-functional nature which yields the negative and positive aspects on teaching and learning process" (Thaidan, 2015: p. 6). Watanabe (2004: p. 19) assumes that "washback is a highly complex rather than monolithic phenomenon".

Surely, washback is a complex phenomenon. Most testing experts agree that high stakes tests may generally have a harmful backwash effect. SSC is a high-stakes achievement test. It is criticized that SSC test items are predictable; presumably, this test will result in harmful backwash. As a consequence, such test will adversely affect teaching and learning.

\subsection{Test's Impact on Materials}

Achievement tests like SSC are closely linked with classroom teaching and teaching materials. Teachers/students are supposed to follow NCTB textbooks. However, the majority of the students and teachers are found to use commercial guide-books/note-books (Alamgir, 2019, 14 October, The Daily Star, Dismal Picture of Secondary Education 37pc teachers rely on "guidebooks"). Numerous reports suggest that commercially published books are greatly admired by the teachers and students for the pragmatic value of those help books. They contain sufficient numbers of model/mock tests following SSC question pattern and their solutions as well. Teachers get some readymade teaching and testing materials which save their time and labor to a large extent. Notably, it is a fact that most teachers are not capable enough to prepare class-lecture and creative question (Habib, 2016). Besides, students also greatly appreciate those notes as they can use these for test taking purposes. It is crucial to explore the reasons why commercially published materials are so randomly used.

The rise of shadow education i.e. an education system that is parallelly run with state sponsored education system, may also be considered as an impact of present tests. A study conducted by the Asian Development Bank in 2012 pointed out the extensive spread of shadow education in Bangladesh. It is a fact that "students nowadays do not sit for their exam without intensive after- school tutoring. Many students go to coaching centers for very subject... Parents don't want to leave any stone unturned for their children's result and thus, run along with their children from one tutor another" Khatun (2019: pp. 1-2). This unhealthy practice encourages exam oriented teaching and learning which ultimately narrows the functional curriculum by encouraging teaching to the test (UNESCO, 2018).

\section{Methodology}

The current study utilised both the qualitative and quantitative methods. Both methods were used to give answer to the research questions developed for the study. For the former, the method employed was document analysis, whereas for 
the latter, a survey was administered. The documents analysed were the National Curriculum (NC) and the past test papers. As for the survey, two separate questionnaires were given to the teachers and students.

\subsection{Context}

This study was conducted in Chittagong city, the second-largest city of Bangladesh which is under Chittagong Education Board. We chose three secondary government schools out of eight and five private secondary schools out of over hundred secondary schools for collecting data among them two were girls' and rest of them were boys' schools. The government exclusively controls government schools. However, it has to be noted that the number of government schools is very small in number, whereas the concerned school authorities administer the nongovernment schools and these are also partly funded by the government, and they are the absolute majority in terms of number. However, both types schools have to comply with government directions. It has to be noted that there are eight education boards in Bangladesh to regulate the entire education administration at secondary and higher secondary levels. The present research context is included in Chittagong Education Board.

\subsection{Participants}

The current study was conducted with 12 teachers and 30 students from 8 secondary (high) schools. They were selected purposefully so that they could respond to the questions related to English reaching and learning practices at SSC level. All teacher-participants are engaged in teaching English with the experience of a minimum of 15 years to a maximum of 32 years. The teacher-participants belonged to both government and private schools. On the other hand, student-participants are from Grade/Class-X (SSC examinee) comprising both boys and girls so that the responses reflect a holistic picture. As there are provisions for coeducation system and separate schools for boys' and girls', this study included students from all three types of schools with a view to ensuring valid, reliable and trustworthy data.

\subsection{Instrumentation and Data Collection}

Two questionnaires were employed to collect data from SSC English teachers and students. The items of the questionnaires were related to SSC EFL tests and their influence, the textbook used, tasks and activities practiced in classrooms, teaching materials other than the NCTB textbooks and language skills taught in the class.

In addition to these questionnaires, we analyzed SSC National Curriculum (NC) 2012, two previous SSC test papers (2016 and 2017). The NC contains objectives of the curriculum, teaching methodology, sample lesson plan, assessment policy, etc. The analysis of the previous test papers helped us understand the structure of the test and the trend of testing. 


\subsection{Data Analysis}

In the above section, we have mentioned that we analyzed $\mathrm{NC}$ and the previous two year's SSC question papers. The analysis of NC helped to discover the education Ministry's guidelines for teaching, teaching materials, aims and objectives of the curriculum and the learning outcomes. On the other hand, the analysis of the past test papers showed what skills are tested and what type of items are usually chosen for the test. Data were also collected from 12 teachers and 30 students through questionnaires to determine the level of interdependence between testing, teaching, and teaching materials. It is important to mention that the researchers considered questionnaire responses until the saturation of data were noticed. To avoid repetition, we did not quote all responses of the participants in the data analysis part. The subsequent discussion is made on the findings by analyzing the collected data. The discussion is presented here in accordance with the research questions where the findings are noted, and excerpts from different data sources are inserted as evidence.

\section{Answer to the Research Question-1}

The following Table 1 shows what data were used to answer the Research Question-1. Below the analysis of National Curriculum (NC), past test papers and questionnaires have been presented sequentially:

Table 1. Methods used to answer Research Question a).

\begin{tabular}{|c|c|c|}
\hline Research Question & Methods & Data sources \\
\hline \multirow{4}{*}{$\begin{array}{l}\text { a) How do SSC EFL tests influence } \\
\text { classroom teaching of English and } \\
\text { selection of teaching materials? }\end{array}$} & \multirow{3}{*}{ Documents } & 1) National Curriculum (NC) \\
\hline & & 2) Past Test Papers \\
\hline & & 1) Teacher Questionnaires \\
\hline & Questionnaire survey & 2) Student Questionnaires \\
\hline
\end{tabular}

By analysisng the above data it was found that SSC EFL tests massively influenced classroom teaching and the selection of the teaching materials because the prime objective of SSC stakeholders is to obtain a good grade. In the subsequent parts, firstly, the NC and then past test papers and finally, questionnaire survey responses (teachers' and students') were analysed.

\subsection{Analysis of National Curriculum (NC) 2012}

The present curriculum considers English as a "skill-based" subject, whereas the former one considered English as a "content-based" subject. The curriculum suggests a teaching and learning policy where learners would find sufficient opportunities to practice language skills. Some of the general objectives of SSC level English teaching that are mentioned in NC are cited below:

"You can listen to a person speaking English and understand what he/she is saying; you can read something and you understand what it is about. Also, you can take part in a conversation/discussion and you can express your ideas/feelings, 
etc. in speaking or in writing. All these functions you can do in English, that is, you can communicate in English" (pp. 8-9). It is understood that the curriculum emphasizes to practice all four major language skills. Its main objectives are to promote communication skills through meticulous and thorough practice. It suggests that English communication skills have to be learned by using the language in everyday communication. So, here English is considered a skill-based subject, and language skills have to be developed by practising it regularly.

The National Curriculum 2012 further states that "the curriculum focuses on teaching-learning English as a skill-based subject so that learners can use English in their real-life situations by acquiring necessary knowledge and skills, learning about cultures and values, developing positive attitudes, pursuing higher education and finding better jobs, nationally and globally" (p. 73). It is clear that the functional curriculum is, in fact, a skill-based one. Here it is shown that one cannot learn English merely by memorising grammar rules and some descriptive/narrative items. Learners have to acquire communicative competence so that they can communicate appropriately in the context.

The NC exemplifies that teachers should not entirely depend on the textbooks when they teach language skills. Textbooks are merely helping tools but not the only resource. It states "skills practice should be done in meaningful contexts, i.e. practice in language use should go beyond the textbook and include real life situations" (NC, P. 73). It is suggested that "there will also be provisions for using supplementary reading materials to develop learners' reading skills" (NC, P. 73). It is clear that the NC acknowledges the value of using authentic materials/created teaching materials for teaching language skills effectively.

It is explicitly found that a CLT- based teaching approach is adopted in the operational curriculum. The document analysed above has identified that the SSC English course was designed to promote communication skills among the learners so that they can effectively communicate in their practical life. The NC views that the present English courses are purely skill-based and it does not endorse rote learning. Teachers are advised to use authentic materials to facilitate communication skills. The curriculum directs that all four language skills have to be taught and tested in an integrated manner.

\subsection{Analysis of Past Test Papers}

SSC EFL tests include two language-based courses/papers each of them carries 100 marks which are known as English $1^{\text {st }}$ Paper and English $2^{\text {nd }}$ Paper. SSC English $1^{\text {ST }}$ Paper test includes reading and writing skills. In the writing part, five types of tasks such as writing a paragraph by answering questions, completing a story, describing graphs and charts, writing informal letter/Email and dialogue writing are included (Figure 1).

SSC English $2^{\mathrm{ND}}$ Paper mainly tests grammar and writing skills. The grammar section comprises of gap filling with clues and without clues, substitution table, right forms of verbs, reported speech, changing sentences, completing sentences, 


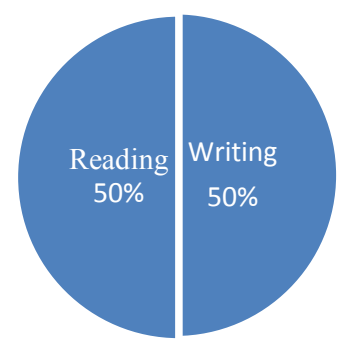

Figure 1. Marks allocation for different skills (English 1st Paper).

tag questions, sentence connectors, punctuations, etc. The composition items include writing a CV with cover letter, writing formal letters/Emails, paragraph writing by listing/narrating/comparison and contrast/cause and effects, and composition writing (Figure 2).

The above data shows that 90 marks are allocated for testing writing skills, 60 marks for grammar skill, while 50 marks for testing reading skill. So it is understood that SSC English syllabus and tests consider developing writing skills as the most important issue.

It is already discussed that English $1^{\text {st }}$ paper test contents which mainly include items related to Reading and Writing skills. A scrutiny of the test revealed that the following types of items are set in English $1^{\text {st }}$ paper writing skill test:

1) Story writing 2) Analysing a graph/chart 3) Letter/email writing 4) Dialogue writing

The analysis of the previous test papers made in the subsequent sections showed how test items are repeated frequently in the tests. Below all of the above-noted writing tasks have been examined separately to ascertain whether the test items are repeated:

Test Item 1: Story Writing

An incomplete story has to be completed by the test takers where a few words are given as clues at the beginning. Students are supposed to show their creativity by completing this story. This task helps to judge students' creativity as well. In short, their communication skills, particularly writing skill is tested through this task.

\begin{tabular}{cc}
\hline \multicolumn{1}{c}{ Item: Story writing } & Instance of repetition \\
\hline $\begin{array}{c}\text { Chittagong Education Board in } 2016 \text { sets: } \\
\text { "Story of a witty crow (a thirsty crow)" }\end{array}$ & Learners studied it for several years since Grade/Class-VII \\
$\begin{array}{cc}\text { Chittagong Education Board in } 2017 \text { sets: } \\
\text { "Story of two rats and a monkey." }\end{array}$ & Learners also studied it for several years since Grade VII \\
\hline
\end{tabular}

The above finding explored that the same item was repeated in different education board's questions.

It is perceived that instead of becoming creative writers, students will gradually become rote learners as the items are repeated regularly. Different Guide/Notebooks that are commercially published contain all of the above stories. Test takers usually memorise the answers from different Note/Guide books 




Figure 2. Marks allocation for different skills (English 2nd Paper).

so that they can reproduce in the exams. It has to be acknowledged that this practice contradicts the norm of communicative language testing.

Test Item 2: Analyse or describe Graphs/Charts

SSC candidates need to analyse or describe graphs/charts. It is expected that students will show their ability to use language effectively while they analyse the graph/chart. It judges the learners' critical ability as well.

\begin{tabular}{cc}
\hline Item: analyse or describe graphs/charts & Instance of repetition \\
\hline $\begin{array}{c}\text { "Internet users in towns and villages" Sets by Chittagong } \\
\text { Education Board in 2016 }\end{array}$ & $\begin{array}{c}\text { Education Board in 2017 } \\
\text { "Choice of professions by different educated youth in }\end{array}$ \\
$\begin{array}{l}\text { Bangladesh" Sets Chittagong Education Board in 2017 } \\
\text { Dhaka Education Board 2015 }\end{array}$ \\
\hline
\end{tabular}

It is found that the task that Chittagong Board set in 2017 was set by Dhaka Board in 2015. Sylhet Board set a task in 2015 which was reproduced by Rajshahi Board in 2017. Cumilla Board copied a task in 2017 from Dhaka Board 2015. So repetition is also a common practice in the selection of this type of task by different education boards.

The intention of the curriculum designers behind the selection of this type (graph/chart analysis) of the task was to evaluate test takers' analytical ability as well as their ability to describe ideas in their language. The NC and TCG suggested developing creativity and critical thinking among students by providing these types of tasks. Here it is evident that such an effective test technique has been inappropriately used at SSC level. Unquestionably, it is a breach of the communicative language testing principle.

Test Item 3: Letter/Email Writing

Learners of the SSC level also need to write letter/Email. To judge students' ability to write about their daily affairs, the test specialists suggested to include this item. The analysis of the past exam papers showed that this item is also repeated regularly on different boards' questions in different academic sessions. Several instances are presented below:

\begin{tabular}{cc}
\hline Item: letter/Email writing & Instance of repetition \\
\hline $\begin{array}{c}\text { "benefits of reading newspaper..." } \\
\text { Sets Chittagong Education Board in 2016 }\end{array}$ & $\begin{array}{c}\text { It was also set three (3) times. } \\
\text { It was set by Chittagong Education Board } \\
\text { in 2009, 2013 and by Jessor Board in 2013. }\end{array}$ \\
"Requesting your cousin for staying & Barishal Board 2016 \\
a few days during summer vacation". \\
Sets Chittagong Education Board in 2017
\end{tabular}




\section{Test Item 4: Dialogue Writing}

The fourth and last writing item is dialogue writing. It is expected that students will engage in dialogue with some of their imaginary partners when they accomplish a task designed on an everyday affair. Dialogues set in different years' questions were studied and found that the same item had been set several times.

\begin{tabular}{cc}
\hline Item: dialogue writing & Instance of repetition \\
\hline $\begin{array}{c}\text { "About your preparation for the ensuing SSC examination." } \\
\text { Sets Chittagong Education Board in 2016 }\end{array}$ & Rajshahi Education Board 2015 \\
"On the necessity of tree plantation." & \\
Sets Chittagong Education Board in 2017 & Sylhet Education Board 2016 \\
\hline
\end{tabular}

The above analysis shows that most of the topics were repeated or some E-mail/letter writing topics are chosen for dialogue writing. This is a deviation from the principles of the curriculum. This test may be considered as a flawed one.

The analysis of writing part test items of English $1^{\text {st }}$ Paper appeared too much problematic. It is obvious that the test items did not reflect CLT principles and the guidelines of the curriculum had been ignored when tests were designed. Moreover, it is feared that the present SSC test patterns might encourage rote learning as the commercially published Guide/Notebooks contain the answer to the above-mentioned test items. It seems that SSC tests have some powerful influence on the selection of teaching and learning materials. In the next part, the test items of the writing part of English $2^{\text {nd }}$ Paper were analyzed.

\subsection{Analysis of English 2nd Paper}

The writing part of this paper asks students to write on the following items:

1) Writing a CV with cover letter 2) Formal letter writing/Email 3) Paragraph writing and 4) Writing composition.

The analysis of previous English $2^{\text {nd }}$ Paper questions has shown that test items are repeated on a regular basis like test items of English $1^{\text {st }}$ Paper. Some instances of repetition from past test papers are provided below.

Test Item 1: CV with job application writing

The 1st item of this paper is to frame their CV with a job application. The analysis of previous test papers showed that test takers were asked to frame their $\mathrm{CV}$ with a job application on the following topics:

\begin{tabular}{cc}
\hline Item: CV with a job application & Instances of repetition \\
\hline $\begin{array}{c}\text { Job application with CV for the post of a "Medical representative" } \\
\text { was set in } 2016 \text { by Chittagong Education Board. }\end{array}$ & It was set twice by others. \\
$\begin{array}{c}\text { Job application for the post of an "English Newscaster" was set in } \\
2017 \text { by Chittagong Education Board. }\end{array}$ & It is not repeated. \\
\hline
\end{tabular}


From the above data, it is noticed that the topics of job application with CV are regularly repeated.

Test Item 2: Letter or Email writing

The $2^{\text {nd }}$ task is a letter or email writing. Here the previous three years' questions are:

\begin{tabular}{cc}
\hline Item: letter or Email writing & Instances of repetition \\
\hline $\begin{array}{c}\text { To set up a debating club ... was set in 2016 by Chittagong } \\
\text { Education Board. }\end{array}$ & $\begin{array}{c}\text { Barishal Education Board 2017, } \\
\text { Rajshahi } 2008 \text { \& } 2017\end{array}$ \\
$\begin{array}{c}\text { Enhancing library facilities ... was set in 2017 by Chittagong } \\
\text { Education Board. }\end{array}$ & $\begin{array}{c}\text { Cumilla Education Board 2009, } \\
\text { Dinajpur Education Board 2014 }\end{array}$ \\
\hline
\end{tabular}

The above data reveals that the frequency of repetition of e-mail/letter writing topic is also alarmingly high.

Test Item 3: Paragraph writing

The third item asks students to write a Paragraph. Below there is an evaluation of the item in different years' question:

\begin{tabular}{cc}
\hline Item: Paragraph writing & Instances of repetition \\
\hline $\begin{array}{c}\text { In 2016 Chittagong Education Board asked students to } \\
\text { write a paragraph on: "Traffic Jam" }\end{array}$ & $\begin{array}{c}\text { This topic was not set in the recent past. } \\
\text { But it had been taught and tested many } \\
\text { times from Grade VI to X. }\end{array}$ \\
$\begin{array}{c}\text { In 2017 Chittagong Education Board asked students to } \\
\text { write paragraph on:" Benefits of Early Rising” }\end{array}$ & $\begin{array}{c}\text { This topic was not repeated in the recent } \\
\text { past. But it had been taught and tested } \\
\text { many times from Grade VI to X. }\end{array}$ \\
\hline
\end{tabular}

The analysis showed that the above item is also repeated.

Test Item 4: Composition writing

Composition writing is the fourth and final writing task of English $2^{\mathrm{ND}}$ Paper. Here is an estimation on the topic selection for composition writing:

\begin{tabular}{|c|c|}
\hline Item: Composition writing & Instances of repetition \\
\hline $\begin{array}{l}\text { In } 2016 \text { Chittagong Education Board asked students to write } \\
\text { a composition on: "Use of Computer in Everyday Life." }\end{array}$ & Was set (4) four times \\
\hline $\begin{array}{l}\text { In } 2017 \text { Chittagong Education Board asked students to write } \\
\text { a composition on: "The Season I like Most/ Spring." }\end{array}$ & $\begin{array}{l}\text { Repeated (9) nine times in different } \\
\text { education boards. }\end{array}$ \\
\hline
\end{tabular}

The picture that is revealed from the above data is worrying for any testing context, especially where it is claimed that tests are designed following CLT principles. It seems that SSC EFL tests failed to uphold the curricular guidelines as learners do not need to show their ability by engaging themselves with genuine communication.

To sum up, the above past test papers analysis has explored the following four features of SSC EFL tests:

1) SSC test items are repeated regularly hence they encourage memorisa- 
tion/rote learning

2) Tests do not reflect the principles of SSC curriculum

3) Authentic tasks are not used

4) Four skills are not tested

When test items remain unchanged years together, the test will certainly be predictable. For this reason, SSC EFL tests have become so much predictable. It is a fact that answer to the SSC test items are available in commercially published materials. Learners and teachers tend to collect those materials to get ready answers. The present test pattern enhances the chances of using commercial materials, i.e. Note/Guide books and for this reason, Note/Guidebook dependent teaching and learning may be encouraged. It is understood that SSC EFL tests might have an overwhelming influence on making the selection of teaching and learning materials

It is apparent that SSC EFL tests do not reflect CLT principles. The present tests ignore the curricular guidelines provided in NC. The NC directed that four language skills have to be tested by upholding CLT principles.

\subsection{Teacher Questionnaire Analysis}

We asked the teachers how guide-books can help students. The participants said that it is a very crucial learning aid for the students. They all need to prepare for the SSC exam. They like it because:

"test items, especially the writing part, is predictable. So, students prefer to memorize some predictable items".

Another teacher said, "most of the questions are set from the previous years' question. Our duty is to make sure that they can answer all the questions".

We also asked a question to the teachers to explore the reason behind using guide-books. Teachers opined that NCTB textbooks do not contain sufficient test items for practising. They replied that "As the NCTB textbooks do not contain mock tests for practising for the SSC tests, I cannot but suggest students buy those." Another teacher said that "Our main goal is to ensure good results in English. Without these guide/notebooks it is impossible. These help books are extremely useful for the test-takers".

On the other hand, only three respondents replied differently.

One said, "It's illegal to use guidebooks in the class." Another replied, "NCTB books are written by experts. So, they are better".

\subsection{Student Questionnaire Analysis}

From the responses of the student participants, it was explored that guide-books are very much popular among them. They all highly admired the guide-books for their effectiveness. They cannot even think of appearing SSC examination without using guide-books.

One said, "It is needed to do well in the examination."

Another participant said, "There are model tests in guidebooks and teachers 
use it. So I need it to follow the class".

$100 \%$ of student-participants consider guide/notebooks as an obligatory part of their academic life. They immensely like it for its utilitarian value. They opined that the contents of the guide/notebooks are chosen in line with SSC EFL question patterns. Guide/notebooks not only contain model questions but also provide answers to those questions. Some of the participants argued like these:

"We memorize the answers to the probable questions from the guidebooks which helps us to get A+ at SSC." This reply suggests that there exists a close relationship between tests and commercially published materials because students found those materials helpful for test preparation.

"Textbooks are not useful for us; on the contrary, guidebooks are valuable for exam because they provide a list of questions and answers to those questions as well. We can learn those and do well in the tests". This participant opined that commercially published materials are better than the NCTB textbooks as textbooks are not written in line with the test.

We also asked the participants what skills are taught and practised regularly in the class. The students replied that SSC EFL tests test only Reading, Writing and Grammar skills. Neither Speaking nor Listening skill is included in the test. So these two skills are hardly taught in the class. None shows interest in these two skills.

One student participant said that "SSC exams don't include Listening and Speaking skills. So we do not spend time practising these skills in class".

Another one replied: "Our target is to obtain A+. So don't waste time practising Listening and Speaking skills". It was found that all of the student participants considered Listening and Speaking are unnecessary language skills.

We found that most of the teacher participants do not feel that Listening and Speaking skills should be taught. Their line of thought is similar to that of students'. They also feel that the skills that are not tested should not be seriously taught. Their total attention is on Reading and Writing skills which are tested. They are even under some pressure from different corners. One said that "No student/guardians/school authority want that I should teach Listening and Speaking skills because in SSC they don't need to answer anything on Listening and Speaking skills." Another teacher said, "I might face resistance from authority if I teach Listening and Speaking skills." However, one participant said that "There is no environment to teach Listening and Speaking skills in my school." While one teacher states "The class is very big, we don't have the sound system." However, three teachers said that they sometimes arrange listening and speaking sessions in the class.

We wanted to know whether Teachers prepare class lectures. They acknowledged that it is not possible to prepare the class lecture. They don't have available resources around them. It consumes a lot of time. They argued that "we don't need to prepare lectures as we get them ready in guidebooks."

"We practice guide books model test all the year round and prepare our stu- 
dents for the SSC test."

Three participants said that they prepare lectures sometimes, not always.

After triangulating the findings from above data analysis it is evident that the tests directly influenced teaching materials selection as well as teaching activities in SSC classrooms. As SSC tests do not include Speaking and Listening Skills, teachers and students also ignore these two important language skills. Furthermore, it is found that SSC EFL tests are extremely predictable which directly persuade students and teachers to become dependent on commercially published guidebook.

\section{Answer to Research Question (RQ)-2}

To answer the second research question, questionnaires were analysed which revealed that SSC EFL tests, teaching and teaching/learning materials were reciprocally related to each other. In the following part questionnaire responses were analysed.

\subsection{Questionnaires Analysis}

To answer the above-stated research questions, we devised questionnaires for teachers and students besides document and past test paper analysis. Both the participants shared their experience, views and opinions regarding the influence of SSC EFL tests on classroom activities.

\subsection{Teachers' and Students' Questionnaires Analysis}

In response to a question, $75 \%$ of them responded that teachers use commercial guidebooks in the class instead of NCTB textbooks as the commercial guide/notebooks are more useful than NCTB textbooks. None of the teacher and student participants said that they used NCTB published "English Grammar and Composition" (English $2^{\text {nd }}$ Paper textbook). However, 25\% of the teacher participants said that they prefer textbooks (English For Today) to guidebooks because it is illegal to use guidebooks in the class. We wanted to collect teachers' views regarding the relationship between SSC EFL tests, teaching and learning materials. Most of the teachers' views echo similar messages. Some of them are quoted in the following part.

"I believe our teaching is carried out to make sure that students can score good grades. To achieve the goals, we use as well as we suggest our students to collect famous guidebooks. These guidebooks are very helpful as students can memorise answers from them". This statement shows how teachers acknowledge the utilitarian value of the guide/notebooks. These commercially published materials are needed to do well in the SSC tests.

Another teacher replied, "I find there exists a deep relationship between test, and teaching and learning materials. We teach what is tested and guidebooks are the best tools for making good results in SSC". The response revealed that a firm relationship exists between tests, teaching and learning materials at SSC level. 
Another participant replied, "There is no scope to avoid guidebooks. Students think that they are very useful. It is true that questions are set from the guidebooks. So, why should I not use them? They contain a lot of model tests and their solutions. We can use them in the class to practice language activities. It is very effective for test preparation. So the mutual relationship between SSC tests, teaching and learning materials is very close".

From the above data it is understood that teachers agreed that SSC EFL tests, teaching and learning materials are mutually related to each other. Test items are predictable (as it is found in the previous part of the data analysis when past tests were analysed). Both teachers and students found that test items are presented in the guidebooks with their answers. So it is due to faulty test, the commercially published books are taught. Hence the mutual relationship between SSC tests, teaching and learning materials is very close.

To conclude, we also sought students, opinions regarding above matter. Like the teachers, students also agreed that tests, teaching and learning of English are mutually related. Below we quote two statements which were provided by them.

"Guidebooks are essential for SSC test preparation. Our teachers use them in class. We need those to follow the class. Another student stated "Our textbooks are not enough for test preparation. We need guidebooks not only for test preparation but also for classwork".

Students' statements justify the teachers' opinions regarding the relationship between tests, teaching and learning of English at SSC level in Bangladesh. The conventional stereotyped test pattern has made teachers and students test-wise. It has also directly contributed to the mushrooming business of commercial teaching-learning materials. It is clearly understood that predictable test is adversely affecting teaching and learning of English.

\section{Summary of the Findings}

The findings of the study indicate that SSC tests have a harmful impact on teaching and they profoundly influence the selection of teaching materials. As everyone's interest lies in final results, test-taking strategies receive full attention. This tendency deviates the teachers from their professional duty and responsibility. Although NCTB textbooks are given to every student free of cost at the beginning of the academic session, students and teachers prefer to use the expensive commercial guide books as they contain model test questions which are very much helpful for SSC test preparation. As most test items can be predicted and guide-books contain their answers, they are tremendously popular among the users.

We can presume an overwhelming effect of the SSC test on our entire educational arrangement. As test centric activities dominate, teaching to the test is feared. The above test pattern encourages students and teachers alike to procure commercially published guidebooks. Due to present test nature, two vital language skills, i.e. Listening and Speaking skills are ignored though they are crucial 
for developing communication skills. It is unthinkable to ignore Listening and Speaking skills in a context where a CLT- based curriculum is functional. This study found an intricate relationship between test, language teaching, and selection of teaching materials. Indeed, the relationship is intricate and multifaceted. We understand every academic activity is test-centric. We are convinced that SSC EFL tests have powerful control over teacher's teaching, learning and selection of materials. Nevertheless, here the power of test is abused.

\section{Recommendations}

The analysis of the above data of the current study revealed that there exists a mutual relationship between SSC EFL tests, teaching and teaching materials. However, this link between them is not at all as per the SSC curricular guidelines. We found that it has some detrimental effects on SSC level education system. We recommend the following measures to improve the existing undesirable condition of our education system:

1) Present SSC EFL tests have to be reformed following the curricular guidelines.

2) Measures have to be taken to ensure beneficial washback.

3) Classroom activities have to be closely monitored by the competent authority to ensure that the curriculum is properly followed.

4) NCTB textbooks should contain sufficient practice items to promote communicative competence.

\section{Conclusion}

Though the study involved a very small data, we understand that SSC EFL tests have a very damaging influence on teaching, and it also influences the teachers and students while they make a selection of teaching and/or learning materials. It seems that the objective of teaching and learning of English is to ensure a good grade at secondary level education which is a clear deviation from the SSC English curriculum. We deduce that the curricular goals and objectives are ignored and test centric teaching-learning activities get preference at SSC level. It is the predictable nature of SSC EFL tests which is blamed for this damaging practice. We assume that only good tests can ensure good teaching and selection of appropriate teaching materials. The present SSC EFL tests fail to ensure it so far.

It is understood that flawed tests, teachers' unwillingness and unpreparedness, business issue and some other contextual limitations encourage teachers and students to use guide/notebooks. Formal textbooks which are designed in line with CLT to develop communication skills in English are kept aside, and teachers and students mostly depend on different commercial books. Justifiably, present SSC EFL tests harmfully influence the selection of the materials that the teachers and students use.

\section{Conflicts of Interest}

The authors declare no conflicts of interest regarding the publication of this paper. 


\section{References}

Al Amin, M., \& Greenwood, J. (2018). The Examination System in Bangladesh and Its Impact: On Curriculum, Students, Teachers and Society. Language Testing in Asia, 8 , 4. https://doi.org/10.1186/s40468-018-0060-9

Alamgir, M. (2019). Dismal Picture of Secondary Education, 37pc Teachers Rely on Guidebooks (pp. 1). The Daily Star.

Ali, C. M., \& Sultana, R. (2016). A Study of the Validity of English Language Testing at the Higher Secondary Level in Bangladesh. International Journal of Applied Linguistics and English Literature, 5, 64-75. https://doi.org/10.7575/aiac.ijalel.v.5n.6p.64

Ali, M. M., \& Walker, A. L. (2014). Bogged Down ELT in Bangladesh: Problem and Policy. English Today, 30, 33-38. https://doi.org/10.1017/S0266078414000108

Ali, M. M., Hamid, M. O., \& Hardy, I. (2018). Ritualisation of Testing: Problematising High-Stakes English-Language Testing in Bangladesh. Compare: A Journal of Comparative and International Education, 1-21. https://doi.org/10.1080/03057925.2018.1535890

Billah, M. (2015). Language and Education Inside and Beyond the Classroom. Dhaka, Bangladesh: Murdhonno.

Brown, J. D. (2005). Testing in Language Program. New York: McGraw-Hill.

Carroll, B. J. (1980). Testing Communicative Performance. London: Pergamon.

English in Action (EIA) (2014). Student Support, English in Action, Primary Lower Secondary Upper Secondary Post-Secondary Non-Tertiary. https://educationinnovations.org/program/english-action

Habib, W. B. (2016) Guide Book Dependent Teaching and Testing (pp. 16). The Daily Star.

Haider, M. Z., \& Chowdhury, T. A. (2012). Repositioning of CLT from Curriculum to Classroom: A Review of the English Language Instructions at Bangladeshi Secondary Schools. International Journal of English Linguistics, 2, 12-22. https://doi.org/10.5539/ijel.v2n4p12

Hamid, M. O., \& Baldauf, R. (2008). Will CLT Bail out the Bogged down ELT in Bangladesh? English Today, 24, 16-24. https://doi.org/10.1017/S0266078408000254

Hughes, A. (2003). Testing for Language Teachers. Cambridge: Cambridge University Press.s

Kabir, M. H. (2007). An Investigation into the Validity and Reliability in Testing Reading and Writing Skills at Higher Secondary Certificate Level in Bangladesh. Essex, UK: University of Essex.

Kabir, M. H. (2008). How Validity Is Ensured in Our Language Test: A Case Study. IIUC Studies, 5.

Kabir, M. H. (2009). How Much Reliable Are Our Language Tests? A Case Study. Crossings, ULAB Journal of English Studies, 2.

Kabir, M. H. (2015). Effect of Bangladeshi English Language Testing on Teaching and Learning: A Case Study. The International Institute for Science, Technology and Education (IISTE).

Khatun, F. (2019) The Rise of Shadow Education. The Daily Star. https://www.thedailystar.net/op-ed/economics/the-rise-shadow-education-117316

National Curriculum (2012). English. Dhaka, Bangladesh: NCTB.

Nunan, D. (1988). Syllabus Design OUP. 
Phan, S. (2008). Communicative Language Testing. TESOL Professional Development. Hawaii Pacific University TESOL Working Paper Series, 6, 3-10.

Rahman, M. M., \& Pandian, A. (2018). A Critical Investigation of English Language Teaching in Bangladesh: Unfulfilled Expectations after Two Decades of Communicative Language Teaching. English Today, 34, 43-49. https://doi.org/10.1017/S026607841700061X

Richards, J. C. (2001). Curriculum Development in Language Teaching. Cambridge: Cambridge University Press. https://doi.org/10.1017/CBO9780511667220

Richards, J. C., Platt, J., \& Weber, H. (1985). Longman Dictionary of Applied Linguistics. London: Longman Group UK Limited.

Sultana, N. (2018). A Brief Review of Washback Studies in the South Asian Countries. The Educational Review, 2, 468-474. https://doi.org/10.26855/er.2018.09.002

Teacher's Curriculum Guide (TCG). Dhaka, Bangladesh: NCTB. Textbooks and Official Documents.

Thaidan, R. (2015). Washback in Language Testing. Education Journal, 4, 5-8. https://doi.org/10.11648/j.edu.20150401.12

Toksoz, I., \& Kilickaya, F. (2017). Review of Journal Articles on Washback in Language Testing in Turkey (2010-2017). Lublin Studies in Modern Languages and Literature, 41, 184. https://doi.org/10.17951/lsmll.2017.41.2.184

UNESCO (2018). The Culture of Testing: Sociocultural Impacts on Learning in Asia and the Pacific. France and UNESCO Bangkok Office.

Watanabe, Y. (2004). Methodology in Washback Studies. In L. Cheng, \& Y. Watanabe (Eds.), 2004 Washback in Language Testing. Mahwah, NJ: Lawrence Erlbaum Associates, Inc.

Weir, C. J. (1990). Communicative Language Testing. London: Prentice Hall International (UK).

Wise, S. L., Kuhfeld, M. R., \& Soland, J. (2019). The Effects of Effort Monitoring with Proctor Notification on Test-Taking Engagement, Test Performance, and Validity. Applied Measurement in Education, 32, 183-192.

https://doi.org/10.1080/08957347.2019.1577248 